\title{
HUBUNGAN TINGKAT PENGETAHUAN DAN POLA ASUH ORANG TUA DENGAN PERKEMBANGAN ANAK PRASEKOLAH DI KELURAHAN LUBUK BUAYA PADANG TAHUN 2019
}

\author{
Wulandari Defera, Aprizal Ponda, Yussie Ater Merry \\ (Poltekkes Kemenkes Padang)
}

\begin{abstract}
Data from the Padang City Health Service 2017 from 23 Puskesmas in Padang City, Lubuk Buaya Health Center $60 \%$ of the highest deviations in child development. One of the factors that influence it is the knowledge and parenting style of parents. The purpose of the study was to determine the relationship between the level of knowledge and parenting styles of parents with the development of preschool children in Darul Falah Kindergarten, Lubuk Buaya Padang Village in 2019. The type of research is an analytical survey with a crosssectional design. The population is all parents and preschool children in Darul Falah Kindergarten as many as 50 people, the sampling technique is the total population. Collecting data using a questionnaire. Data analysis with univariate and bivariate using ChiSquare. It was found that $36 \%$ of preschool children's development was not appropriate, $26 \%$ of respondents had poor parental knowledge, $34 \%$ of parenting styles were at risk. The relationship between the respondent's level of knowledge with child development and the relationship between parenting patterns and child development obtained $p$ value $=0.000$ ( $p$ $<0.05$ ). There is a relationship between the level of knowledge and parenting patterns of parents with the development of preschool children in Darul Falah Kindergarten, Lubuk Buaya Padang Village in 2019. It is hoped that health workers will socialize stimulation of child development with counseling and preschool health promotion for parents.
\end{abstract}

Keywords: Parent's knowledge; Parent's nurture; Preschool children development

\begin{abstract}
Abstrak
Data Dinas Kesehatan Kota Padang 2017 dari 23 Puskesmas di Kota Padang, Puskesmas Lubuk Buaya $60 \%$ tertinggi penyimpangan perkembangan anak. Salah satu faktor yang mempengaruhinya adalah pengetahuan dan pola asuh orang tua. Tujuan penelitian untuk mengetahui hubungan tingkat pengetahuan dan pola asuh orang tua dengan perkembangan anak prasekolah di TK Darul Falah Kelurahan Lubuk Buaya Padang tahun 2019. Jenis penelitian yaitu survey analitik dengan desain cross sectional. Populasi adalah semua orang tua dan anak prasekolah di TK Darul Falah sebanyak 50 orang, teknik pengambilan sampel dengan total populasi. Pengumpulan data menggunakan kuesioner. Analisis data dengan univariat dan bivariat menggunakan Chi-Square. Didapatkan sebanyak 36\% perkembangan anak prasekolah tidak sesuai, $26 \%$ responden tingkat pengetahuan orang tua kurang baik, $34 \%$ pola asuh orang tua berisiko. Hubungan tingkat pengetahuan responden dengan perkembangan anak dan hubungan pola asuh orang tua dengan perkembangan anak didapatkan $p$ value $=0,000$ ( $p<0,05$ ). Ada hubungan tingkat pengetahuan dan pola asuh orang tua dengan perkembangan anak prasekolah di TK Darul Falah Kelurahan Lubuk Buaya Padang tahun 2019. Diharapkan bagi petugas kesehatan untuk menyosialisasikan stimulasi perkembangan anak dengan penyuluhan dan promosi kesehatan prasekolah untuk orang tua.
\end{abstract}

Kata Kunci : Tingkat Pengetahuan; Pola Asuh Orang Tua; Perkembangan Anak Prasekolah 


\section{PENDAHULUAN}

Perkembangan merupakan bertambahnya struktur dan fungsi tubuh yang lebih kompleks dalam kemampuan gerak kasar dan gerak halus bicara dan bahasa serta sosialisasi dan kemandirian. Perkembangan terjadi bersamaan dengan pertumbuhan. Setiap pertumbuhan disertai dengan perubahan fungsi. Misalnya perkembangan intelegensia pada seorang anak akan menyertai pertumbuhan otak dan serabut syaraf. ${ }^{1}$

Masalah tumbuh kembang anak merupakan masalah yang perlu diketahui atau dipahami sejak konsepsi hingga dewasa. Berdasarkan data dari World Health Organitation (WHO) melaporkan bahwa 5-25\% anak-anak usia prasekolah menderita disfungsi otak minor, termasuk gangguan perkembangan motorik halus. Data United Nations International Children's Emergency Fund (UNICEF) Indonesia tahun 2012 menyebutkan bahwa 1 dari 3 anak balita terhambat pertumbuhan dan perkembangannya, sedangkan secara global dilaporkan anak yang mengalami gangguan berupa kecemasan sekitar $9 \%$, mudah emosi 11-15\% dan gangguan perilaku 9-15\%. ${ }^{2}$ Departemen Kesehatan RI juga melaporkan 0,4 juta (16\%) balita Indonesia mengalami gangguan perkembangan, baik perkembangan motorik halus dan kasar, gangguan pendengaran, kecerdasan kurang dan keterlambatan bicara. Ditindaklajuti dengan hasil data Dinas Kesehatan sebesar 85.779 (62,02\%) anak usia prasekolah mengalami gangguan perkembangan. ${ }^{3}$

Berdasarkan berbagai penelitian, penyimpangan perkembangan yang sering ditemukan adalah retardasi mental $3 \%$, palsi selebral 1 diantara 200, kesulitan belajar dan sindrom yang menyangkut konsentrasi dan perhatian anak sekitar 5-7\%. ${ }^{4,5}$ Beberapa gangguan yang sering ditemukan dalam perkembangan anak antara lain gangguan bicara dan bahasa, cerebral palsy, down syndrome, gangguan autisme, retardasi mental, gangguan pemusatan dan hiperaktif. ${ }^{6}$ Gangguan perkembangan bicara dan bahasa merupakan gangguan perkembangan sering ditemukan pada anak 3-16 tahun, sedangkan berdasarkan Soetjiningsih \& Gde Ranuh tahun 2015, diperkirakan angka kejadiannya berkisar antara $1 \%$ - 32\% pada populasi normal. ${ }^{7}$

Menurut National Center for Health Statistics (NCHS), berdasarkan atas laporan orang tua, angka kejadian gangguan bicara dan bahasa 0,9\% pada anak dibawah umur 5 tahun dan 1,94\% pada anak usia 5-14 tahun. Dari hasil evaluasi langsung terhadap anak usia sekolah, angka kejadiannya 3,8 kali lebih tinggi. Berdasarkan hal ini diperkirakan gangguan bicara dan bahasa pada anak-anak adalah sekitar 4\% sampai 5\%,,7 sedangkan berdasarkan data hasil Riset Kesehatan Dasar (Riskesdas) perbandingan indeks perkembangan anak pada anak usia 36-59 bulan tahun 2018 Indonesia mendapatkan total indeks perkembangan sebesar 88,3\% masih dibawah Thailand pada tahun 2015 sebesar $91,1 \%$ dan Vietnam pada tahun 2014 sebesar $88,7 \% .^{8}$ 
Banyak faktor yang mempengaruhi pertumbuhan dan perkembangan anak salah satunya adalah pola asuh. Pola asuh orang tua terhadap pertumbuhan dan perkembangan anak-anaknya sangat diperlukan terutama pada saat mereka masih berada di bawah lima tahun/balita. Orang tua salah satunya adalah ibu, merupakan tokoh sentral dalam tahap pertumbuhan dan perkembangan seorang anak. Ibu berperan sebagai pendidik pertama dalam keluarga, sehingga ibu perlu dibekali pengetahuan dan keterampilan agar mengerti dan terampil dalam melaksanakan tumbuh kembang anak secara baik dan sesuai dengan tahapan perkembangan anak. Hal ini sangat mungkin dilaksanakan apabila orang tua khususnya ibu mempunyai pengetahuan yang baik tentang arti penting tumbuh kembang anak. ${ }^{8,9}$

Salah satu faktor yang mempengaruhi perkembangan dalam keluarga adalah pengetahuan orang tua. Pengetahuan orang tua berpengaruh terhadap perkembangan anak terutama pengetahuan ibu. Menurut Pediatri, pengetahuan ibu yang rendah tentang perkembangan anak untuk terjadinya keterlambatan perkembangan anak, disebabkan karena ibu belum tahu cara memberikan stimulasi perkembangan anaknya. ${ }^{9}$ Perkembangan seorang anak jika mengalami gangguan akan bermuara pada suatu problem psikososial diberbagai bidang, seperti di bidang akademik yaitu gagal sekolah dan mogok sekolah. Menurut Soetjiningsih, dalam hal lainnya seperti gangguan pemusatan perhatian dan hiperaktivitas, retardasi mental, temper tantrum (emosi meledak-ledak), enuresis (mengompol) bahkan gangguan bicara dan bahasa berkelanjutan. Dalam menilai perkembangan anak khususnya anak prasekolah dapat dilakukan salah satunya dengan menggunakan Kuesioner Pra Skrining Perkembangan (KPSP). KPSP adalah salah satu alat deteksi dini yang sudah baku dan dikeluakan oleh Kemenkes serta sudah teruji validitasnya. Jenis penyimpangan yang dideteksi melalui KPSP yaitu gerak kasar, gerak halus, kemampuan bahasa dan sosialisasi kemandirian. ${ }^{10}$

Upaya untuk membantu agar tumbuh kembang optimal, deteksi dini adanya penyimpangan perlu dilaksanakan oleh semua pihak mulai dari tingkat keluarga, petugas kesehatan, kader kesehatan sampai dokter spesialis dan di semua tingkat pelayanan kesehatan mulai dari tingkat dasar sampai semua pelayanan yang lebih spesialis. Melakukan deteksi dini penyimpangan tumbuh kembang artinya melakukan skrining atau mendeteksi secara dini adanya penyimpangan tumbuh kembang balita dan prasekolah, termasuk menindaklanjuti setiap keluhan orang tua terhadap masalah tumbuh kembang anaknya. ${ }^{1}$

Data dari Dinas Kesehatan Kota (DKK) Padang menyebutkan bahwa pada tahun 2017 dengan jumlah anak balita yang sudah dideteksi melalui deteksi dini tumbuh kembang (DDTK) adalah sebesar 61.783 orang dan anak balita dengan jumlah penyimpangan sebesar 212 orang. Sedangkan tercatat jumlah Anak Prasekolah (APRAS) yang sudah 
dideteksi melalui DDTK 29.222 orang dan jumlah APRAS dengan jumlah penyimpangan sebesar 59 orang. ${ }^{13}$ Cakupan ini sudah mencapai target SPM (Standar Pelayanan Minimal) Sumbar 2016 yaitu sebesar 90\%. Sementara dari 23 Puskesmas yang ada di Kota Padang, didapatkan DDTK di Wilayah Kerja Puskesmas Lubuk Buaya sebesar 60 \% cakupan tertinggi dengan penyimpangan perkembangan terdapat di kelurahan Lubuk Buaya Padang. Cakupan DDTK APRAS tertinggi di kelurahan Lubuk Buaya Padang adalah TK Darul Falah dengan didapati $40 \%$ adanya penyimpangan perkembangan anak prasekolah yang menyimpang. Oleh karena itu, perlu dilakukan penelitian yang bertujuan untuk menggali informasi apakah adanya hubungan antara tingkat pengetahuan dan pola asuh orang tua dengan perkembangan anak usia prasekolah di TK Darul Falah Kelurahan Lubuk Buaya tahun 2019.

\section{METODE PENELITIAN}

Jenis penelitian ini yaitu survey analytic dengan desain cross sectional study. Penelitian ini dilaksanakan pada bulan Januari-Maret 2019 di TK Darul Falah Kelurahan Lubuk Buaya Padang. Populasi dalam penelitian ini adalah semua orang tua yang memiliki anak prasekolah dan anak prasekolah di TK Darul Falah Kelurahan Lubuk Buaya Padang. Sampel penelitian yaitu semua populasi dijadikan sampel penelitian (total populasi) ${ }^{11}$ dengan jumlah sebanyak 50 orang. Teknik pengambilan sampel dalam penelitian ini mengambil seluruh anggota populasi sebagai responden atau sampel yaitu semua responden kelas $\mathrm{B} 1, \mathrm{~B} 2, \mathrm{~B} 3$ dan $\mathrm{B} 4$.

Alat/instrumen yang digunakan pada penelitian ini adalah menggunakan kuesioner untuk mengukur tingkat pengetahuan orang tua dengan perkembangan anak prasekolah yang terdiri dari 20 pertanyaan. Kuesioner untuk mengetahui pola asuh orang tua dengan perkembangan anak prasekolah yang terdiri dari 30 pernyataan, serta menggunakan KPSP 60-72 bulan untuk mengukur perkembangan anak prasekolah sesuai usianya.

Peneliti secara langsung mengumpulkan hasil pengisian angket dan wawancara responden yang telah ditetapkan sesuai kriteria inkusi dan ekslusi. Untuk menilai tingkat pengetahuan dan pola asuh orang tua menggunakan kuesioner, sedangkan pengumpulan data untuk mengukur perkembangan anak prasekolah, peneliti melakukan observasi secara langsung menggunakan pedoman KPSP. Selanjutnya, pengolahan data dilakukan secara manual. Untuk analisis data dilakukan secara univariat dalam bentuk tabel distribusi frekuensi sehingga diketahui variasi dari masing-masing variabel, teknik analisis ini adalah dengan komputerisasi dan analisis bivariat untuk mengetahui hubungan variabel bebas dengan varibel terikat menggunakan uji statistik Chi-Square. 


\section{HASIL PENELITIAN}

Gambaran umum responden dapat dilihat pada tabel berikut :

Tabel 1. Distribusi Frekuensi Perkembangan Anak Prasekolah di TK Darul Falah Kelurahan Lubuk Buaya Padang Tahun 2019

\begin{tabular}{ccc}
$\begin{array}{c}\text { Perkembangan Anak } \\
\text { Prasekolah }\end{array}$ & $\mathbf{f}$ & $\%$ \\
\hline Tidak sesuai & 18 & 36 \\
\hline Sesuai & 32 & 64 \\
\hline Jumlah & 50 & 100 \\
\hline
\end{tabular}

Pada penelitian ini didapatkan bahwa kurang dari separuh yaitu 36\% responden mengalami perkembangan anak prasekolah yang tidak sesuai.

Tabel 2. Distribusi Frekuensi Tingkat Pengetahuan Orang Tua di TK Darul Falah Kelurahan Lubuk Buaya Padang Tahun 2019

Tingkat Pengetahuan Orang Tua f $\%$

$\begin{array}{ccc}\text { Kurang Baik } & 13 & 26 \\ \text { Baik } & 37 & 74 \\ \text { Jumlah } & 50 & 100\end{array}$

Berdasarkan tabel 2 didapatkan bahwa kurang dari separuh yaitu 26\% responden yang tingkat pengetahuan orang tua kurang baik.

Tabel 3. Distribusi Frekuensi Pola Asuh Orang Tua di TK Darul Falah Kelurahan Lubuk Buaya Padang Tahun 2019

\begin{tabular}{ccc}
\hline Pola Asuh Orang Tua & $\mathbf{f}$ & $\%$ \\
\hline Berisiko & 17 & 34 \\
\hline Tidak Berisiko & 33 & 66 \\
\hline Jumlah & 50 & 100 \\
\hline
\end{tabular}

Berdasarkan tabel 3 didapatkan bahwa kurang dari separuh yaitu 34\% responden yang pola asuh orang tuanya berisiko. Pola asuh berisiko yang dimaksudkan adalah pola asuh otoriter sebesar $88,3 \%$ dan pola asuh permisif sebesar $11,7 \%$.

Tabel 4. Hubungan Tingkat Pengetahuan Orang Tua dengan Perkembangan Anak Prasekolah di TK Darul Falah Kelurahan Lubuk Buaya Padang Tahun 2019 Perkembangan Anak

\begin{tabular}{|c|c|c|c|c|c|c|c|}
\hline \multirow{3}{*}{ Tingkat pengetahuan } & \multicolumn{4}{|c|}{$\begin{array}{c}\text { Perkembangan Anak } \\
\text { Prasekolah }\end{array}$} & \multirow{2}{*}{\multicolumn{2}{|c|}{ Total }} & \multirow{3}{*}{$P$ value } \\
\hline & \multicolumn{2}{|c|}{ Tidak Sesuai } & \multicolumn{2}{|c|}{ Sesuai } & & & \\
\hline & $f$ & $\%$ & $f$ & $\%$ & f & $\%$ & \\
\hline Kurang Baik & 12 & 92,3 & 1 & 7,7 & 13 & 100,0 & 0,000 \\
\hline Baik & 6 & 16,2 & 31 & 83,8 & 37 & 100,0 & \\
\hline Jumlah & 18 & 36.0 & 32 & 64,0 & 50 & 100.0 & \\
\hline
\end{tabular}

Berdasarkan tabel 4 di atas didapatkan bahwa dari 13 responden yang memiliki tingkat pengetahuan yang kurang baik terdapat 12 responden atau $(92,3 \%)$ perkembangan anak prasekolah yang tidak sesuai, lebih kecil dibandingkan dengan 1 responden atau $(7,7 \%)$ 
perkembangan anak yang sesuai. Hasil uji statistik didapatkan nilai $p=0,000(p<0,05)$ berarti dapat disimpulkan $\mathrm{H}_{0}$ ditolak dan $\mathrm{Ha}$ diterima, artinya ada hubungan tingkat pengetahuan orang tua dengan perkembangan anak prasekolah di TK Darul Falah Kelurahan Lubuk Buaya Padang tahun 2019.

Tabel 5. Hubungan Pola Asuh dengan Perkembangan Anak Prasekolah di TK Darul Falah Kelurahan Lubuk Buaya Padang Tahun 2019

\begin{tabular}{|c|c|c|c|c|c|c|c|}
\hline \multirow{3}{*}{ Pola Asuh } & \multicolumn{4}{|c|}{$\begin{array}{c}\text { Perkembangan Anak } \\
\text { Prasekolah }\end{array}$} & \multirow{2}{*}{\multicolumn{2}{|c|}{ Total }} & \multirow{3}{*}{$P$ value } \\
\hline & \multicolumn{2}{|c|}{ Tidak Sesuai } & \multicolumn{2}{|c|}{ Sesuai } & & & \\
\hline & $f$ & $\%$ & $f$ & $\%$ & $f$ & $\%$ & \\
\hline Berisiko & 15 & 88,2 & 2 & 11,8 & 17 & 100,0 & 0,000 \\
\hline Tidak Berisiko & 3 & 9,1 & 30 & 90,9 & 33 & 100,0 & \\
\hline Jumlah & 18 & 36,0 & 32 & 64,0 & 50 & 100,0 & \\
\hline
\end{tabular}

Berdasarkan tabel 5 di atas, didapatkan bahwa dari 17 responden yang pola asuh berisiko terdapat 15 orang atau $(88,2 \%)$ perkembangan anak prasekolah yang tidak sesuai, lebih kecil dibandingkan dengan 2 orang atau $(11,8 \%)$ perkembangan anak yang sesuai. Hasil uji statistik didapatkan nilai $p=0,000(p<0,05)$ berarti dapat disimpulkan $\mathrm{H}_{0}$ ditolak dan Ha diterima, artinya ada hubungan pola asuh orang tua dengan perkembangan anak prasekolah di TK Darul Falah Kelurahan Lubuk Buaya Padang tahun 2019.

\section{PEMBAHASAN}

\section{a. Perkembangan Anak Prasekolah}

Berdasarkan dari hasil penelitian yang didapat bahwa kurang dari separuh yaitu sebesar 36\% responden mengalami perkembangan anak prasekolah yang tidak sesuai. Dimana $65 \%$ diantaranya tidak dapat menggambar sedikitnya 6 bagian tubuh manusia dan $50 \%$ menangkap bola kecil sebesar bola tenis/bola kasti hanya dengan kedua tangan dengan tepat.

Perkembangan masa anak meliputi kemampuan berbahasa, kreativitas, kesadaran sosial, emosional dan intelegensi akan berjalan sangat cepat. Dalam perkembangan ini, otak anak lebih terbuka untuk belajar dan diperkaya serta lebih peka terhadap lingkungan terutama lingkungan yang tidak mendukung, termasuk kemiskinan dan stimulasi yang kurang, sehingga masa ini disebut juga sebagai "Masa Keemasan" (Golden Age Period) atau "Jendela Keemasan" (Window of Opportunity) atau "Masa Kritis" (Critical Period). ${ }^{5}$

Perkembangan anak prasekolah yang tidak sesuai biasanya berkaitan dengan gangguan pada proses perkembangannya, bila gangguan tersebut tidak segera diatasi maka akan berlanjut pada fase perkembangan berikutnya yaitu fase perkembangan anak sekolah, sehingga dapat menghambat proses perkembangan yang optimal. Dengan demikian, penting bagi orang tua, tenaga kesehatan serta guru untuk memahami 
permasalahan-permasalahan anak agar dapat meminimalkan munculnya permasalah perkembangan yang terjadi. ${ }^{11}$ Hasil penelitian ini sejalan dengan penelitian sebelumnya yang dilakukan oleh Mukhtar Sri di Kelurahan Bukit Kecamatan Pauh menemukan bahwa kurang dari separuh (48,3\%) responden memiliki anak dengan perkembangan tidak sesuai.

Menurut asumsi peneliti bahwa masih banyak perkembangan anak prasekolah pada penelitian ini yang tidak sesuai, sedangkan responden dalam penelitian telah mendapatkan pengetahuan dan pendidikan yang sesuai dari pihak sekolah dan orang tua. Adapun indikator yang tidak sesuai antara lain anak tidak dapat membuat dan menggambar minimal 6 bagian tubuh orang, menyebutkan lawan kata dari kata seperti "kecil" dan "besar" serta menangkap bola kecil sebesar bola tenis/ bola kasti hanya dengan menggunakan kedua tangannya. Hal ini kemungkinan disebabkan masih kurangnya pengetahuan ibu mengenai stimulasi dan masih kurangnya pemberian stimulasi pada anak, sebagaimana terdapat masih banyaknya kesalahan pada kuesioner nomor 12 mengenai stimulasi gerak kasar pada usia 4 tahun.

\section{b. Tingkat Pengetahuan}

Berdasarkan hasil penelitian didapatkan bahwa kurang dari separuh yaitu sebesar $26 \%$ responden yang tingkat pengetahuan orang tua kurang baik. Dari hasil penelitian didapatkan 13 orang responden yang berpengetahuan kurang baik terdapat $78 \%$ responden menjawab salah pada kuesioner nomor 9 mengenai aspek perkembangan, 50\% responden menjawab salah pada kuesioner 12 mengenai pengetahuan stimulasi pada anak untuk latihan gerak/motorik kasar pada usia 3-4 tahun, 50\% responden menjawab salah pada kuesioner 19 mengenai faktor infeksi sewaktu hamil dapat berpengaruh terhadap perkembangan anak, $48 \%$ responden menjawab salah pada kuesioner 11 mengenai pengetahuan stimulasi latihan gerak/motorik kasar pada anak usia 3 tahun dan 44\% responden menjawab salah pada kuesioner nomor 3 mengenai pernyataan perkembangan anak perempuan sama atau tidak dengan anak laki-laki.

Pengetahuan orang tua tentang perkembangan anak untuk mengetahui risiko yang mungkin terjadi. Kurangnya pengetahuan dari orang tua dan masyarakat terhadap kesehatan mengakibatkan mereka tidak sesuai dengan nilai-nilai kesehatan dan masih banyak faktor-faktor yang mempengaruhinya antara lain pendidikan, informasi dan media massa, sosial budaya ekonomi, lingkungan, pengalaman dan usia. Penilaian tingkat pengetahuan pada responden ini dapat dilihat dari hasil kuesioner yang dijawab oleh responden. Hasil kuesioner menunjukkan bahwa dari 20 buah pertanyaan yang diajukan, 78 $\%$ responden menjawab salah pada pertanyaan tentang aspek perkembangan anak dan $50 \%$ responden menjawab salah pada pertanyaan mengenai perkembangan motorik/gerakan kasar pada anak serta faktor yang berhubungan dengan perkembangan anak. $^{12}$ 
Sebagian besar responden yang memiliki pengetahuan baik tentang perkembangan anaknya karena sudah adanya informasi yang didapat baik dari media informasi seperti internet, radio dan televisi, tenaga pengajar serta petugas kesehatan. Hasil penelitian ini sejalan dengan penelitian sebelumnya yang dilakukan oleh Handayani mengenai hubungan tingkat pengetahuan orang tua tentang stimulasi verbal dengan perkembangan anak prasekolah di TK PGRI 116 Bangetayuwetan tahun $2012 .{ }^{13}$

Menurut asumsi peneliti, bahwa kurangnya pengetahuan orang tua pada penelitian ini disebabkan karena pengetahuan ibu tentang perkembangan anak antara lain responden menjawab salah sebanyak $78 \%$ pada kuesioner mengenai aspek perkembangan anak, responden menjawab salah sebanyak $50 \%$ mengenai perkembangan motorik/gerak kasar anak sesuai usianya dan sebanyak $50 \%$ mengenai infeksi yang berpengaruh terhadap perkembangan anak. Hal ini dimungkinkan masih kurangnya informasi berupa penyuluhan dan promosi kesehatan mengenai perkembangan anak.

\section{c. Pola Asuh Orang Tua}

Berdasarkan dari hasil penelitian didapatkan bahwa kurang dari separuh yaitu sebesar (36\%) responden dengan pola asuh yang berisiko. Dari 17 responden yang pola asuh asuh berisiko terdapat $88,2 \%$ responden dengan pola asuh otoriter dan $11,8 \%$ responden dengan pola asuh permisif. Hasil penelitian ini sejalan dengan penelitian Apriastuti tentang analisis tingkat pendidikan dan pola asuh orang tua dengan perkembangan anak usia 48-60 bulan di Desa Mudal Boyolali tahun 2013, hasil penelitian ini menunjukkan bahwa sebagian kecil orang tua memiliki pola asuh otoriter dan permisif terhadap anaknya.

Perkembangan anak dapat dioptimalkan selama masa kehamilan sang ibu dengan cara stimulasi otak anak, nutrisi yang cukup dan cinta kasih orang tua atau pola pengasuhan yang sesuai sedari dini mulai diterapkan. Pola asuh orang tua tentang perkembangan anaknya sangat membantu anak mencapai dan melewati perkembangan sesuai tingkatan usianya normal, dengan lebih mengetahui tentang perkembangan anaknya diharapkan perkembangan anak lebih optimal dan maksimal sehingga kedepannya akan menghasilkan penerus generasi yang lebih baik. ${ }^{11}$

Orang tua memiliki cara dan pola tersendiri dalam mengasuh dan membimbing anaknya. Cara dan pola tersebut tentu akan berbeda antara satu keluarga dengan keluarga lainnya, dengan melihat gambaran tentang sikap dan perilaku orang tua dan anak dalam berinteraksi, berkomunikasi selama mengadakan kegiatan pengasuhan. Dalam kegiatan pengasuhan ini orang tua akan memberikan perhatian, peraturan, disiplin, hadiah dan hukuman, serta tanggapan-tanggapan terhadap keinginan anaknya. Sikap dan perilaku serta kebiasaan orang tua selalu dilihat, dinilai dan ditiru oleh anak-anaknya yang kemudian semua itu baik secara sadar maupun tidak sadar akan diresapi, ditiru kemudian menjadi 
kebiasaan pula bagi anak-anaknya. Hal ini akan berpengaruh terhadap perkembangan anak.

Menurut asumsi peneliti bahwa masih banyak pola asuh orang tua yang berisiko pada penelitian ini. Adapun indikitor yang berisiko antara lain pola orang tua dalam mengawasi anaknya, menjadwalkan kegiatan anak serta pola pemberian hukuman atau sanksi apabila anak melanggar. Hal ini kemungkinan disebabkan masih kuatnya budaya ototiter atau mengekang dalam lingkungan sekitar sehingga ketergantungan anak terhadap orang tua menjadi semakin tinggi serta kekhawatiran yang tinggi dari orang tua terhadap kegiatan yang akan dilakukan oleh anak.

\section{d. Hubungan Tingkat Pengetahuan Orang Tua dengan Perkembangan Anak Prasekolah}

Berdasarkan tabel diketahui bahwa perkembangan anak yang tidak sesuai lebih banyak pada responden dengan tingkat pengetahuan yang kurang baik yaitu sebesar $(92,3 \%)$ dibandingkan responden dengan tingkat pengetahuan yang baik (16,2\%). Hasil uji statistik (Chi-Square) didapatkan nilai $p=0,000(p<0,05)$ berarti ada hubungan tingkat pengetahuan dengan perkembangan anak prasekolah di TK Darul Falah Kelurahan Lubuk Buaya Padang tahun 2019. Pengetahuan merupakan hasil dari tahu yang terjadi setelah seseorang melakukan penginderaan pada objek dan terjadi melalui panca indera manusia. Pengetahuan atau kognitif merupakan domain yang sangat penting dalam membentuk tindakan seseorang (overt behavior). Perilaku yang didasari oleh pengetahuan lebih baik daripada perilaku yang tidak didasari oleh pengetahuan. ${ }^{13}$

Penelitian ini sejalan dengan penelitian Koseregan dan Ismanto mengenai hubungan tingkat pengetahuan orang tua tentang stimulasi dini dengan perkembangan anak usia 4-5 tahun di Desa Ranoketang Atas tahun 2013. Dari hasil penelitiannya didapatkan kurang dari separuh yaitu sebesar $37,5 \%$ pengetahuan orang tua yang kurang baik, dimana nilai $p=$ 0,005 dengan uji statistik kolmogrov yang artinya terdapat hubungan tingkat pengetahuan orang tua tentang stimulasi dini dengan perkembangan anak usia 4-5 tahun di Desa Ranoketang Atas tahun 2013. ${ }^{15}$ Penelitian ini juga sejalan dengan penelitian Aida Aisyatuz Zahro mengenai hubungan tingkat pengetahuan ibu tentang stimulasi verbal dengan perilaku membaca cerita pada anak di Dusun Petet Desa Tuntang Kecamatan Tuntang Kabupaten Semarang tahun 2009, dari hasil penelitian didapatkan ibu yang berpengetahuan tinggi lebih dari separuh atau sebanyak $59,7 \%$, sedang $29,2 \%$ dan rendah $11,1 \%$. Dimana diperoleh nilai $p$ sebesar 0,000 yang menunjukkan adanya hubungan yang signifikan antara tingkat pengetahuan stimulasi verbal dengan perilaku membaca cerita pada anak. ${ }^{15}$

Namun dari hasil penelitian didapatkan adanya $7,7 \%$ orang tua yang memiliki pengetahuan kurang baik tetapi memiliki anak yang perkembangannya sesuai. Hal ini dikarenakan pengetahuan orang tua kurang baik tetapi dalam pemberian stimulasi dan 
rangsangan perkembangan dapat dilimpahkan kepada pihak sekolah atau TK. Orang tua memiliki peranan penting dalam optimalisasi perkembangan seorang anak. Orang tua harus selalu memberi rangsangan atau stimulasi kepada anak dalam semua aspek perkembangan baik motorik kasar, halus, bahasa serta berkomunikasi dan bersosialisasi. Stimulasi yang berlandaskan dari pengetahuan orang tua harus diberikan secara rutin dan berkesinambungan dengan kasih sayang serta metode bermain dan belajar, sehingga perkembangan anak akan berjalan optimal dan kurangnya stimulasi dari orang tua dapat menyebabkan keterlambatan perkembangan anak.

Menurut asumsi peneliti, terdapatnya hubungan bermakna tingkat pengetahuan orang tua dengan perkembangan anak prasekolah karena pengetahuan orang tua sangat menentukan dalam pencapaian tahap perkembangan seperti motorik/gerakan kasar, halus, bahasa dan berkomunikasi sera bersosialisasi. Semakin tinggi pengetahuan orang tua maka berbanding lurus dengan perkembangan anak sesuai usianya, sedangkan semakin rendah pengetahuan orang tua maka didapatkannya penyimpangan perkembangan perkembangan anak sesuai usianya. Untuk itu, hendaknya pengetahuan orang tua dapat ditambah dengan adanya bidan dan tenaga kesehatan lainnya sebagai ujung tombak layanan kesehatan dan promosi kesehetan khususnya dalam perkembangan anak baik berupa informasi dengan penyuluhan menggunakan leaflet, video dan lainnya.

\section{e. Hubungan Pola Orang Tua dengan Perkembangan Anak Prasekolah}

Berdasarkan penelitian didapatkan bahwa perkembangan anak yang tidak sesuai lebih banyak dari pada responden dengan pola asuh yang berisiko $(88,2 \%)$ dibandingkan responden dengan pola asuh yang tidak berisiko (9,1\%). Hasil uji statistik (Chi-Square) didapatkan nilai $p=0,000(p<0,05)$ berarti terdapat hubungan pola asuh orang tua dengan perkembangan anak prasekolah di TK Darul Falah Kelurahan Lubuk Buaya Padang tahun 2019. Mengasuh anak dapat menjadi sesuatu yang menantang, tetapi membutuhkan waktu dan energi ekstra, strategi-strategi baru untuk mengasuh anak. Belajar cara-cara baru mengasuh anak mungkin sulit dilakukan, tetapi orang tua harus mencurahkan usaha untuk mengurusi anak. ${ }^{14}$

Pola pengasuhan dipengaruhi oleh budaya yang ada di lingkungan karena segala sesuatu yang ada dalam keluarga baik yang berupa benda-benda dan orang-orang serta peraturan-peraturan dan adat istiadat yang berlaku dalam keluarga itu sangat berpengaruh dan menentukan corak perkembangan anak serta pengertahuan orang tua. ${ }^{15}$

Hasil penelitian ini sejalan dengan penelitian sebelumnya oleh Mukhtar Sri yang menemukan bahwa adanya hubungan pola asuh orang tua dengan perkembangan anak di Kelurahan Bukit Kecamatan Pauh tahun 2017 dengan nilai $p=0,001$. Dari hasil penelitian didapatkan dari 30 pola asuh yang kurang baik sebanyak $70 \%$ diantaranya memiliki perkembangan anak yang tidak sesuai. Penelitian ini juga sejalan dengan penelitian Dwi 
Setia mengenai hubungan tingkat pola asuh dengan perkembangan sosial anak usia dini di TK Negeri Pembina 2 Kota Jambi tahun 2017. Dari hasil penelitiannya didapatkan nilai koefisien korelasi dari pola asuh otoriter sebanyak 0,0514 , permisif 0,613 , penelantaran 0,275 dan demokratis 0,232 . Dimana diperoleh nilai signifikansi pola asuh lebih besar dari 0,05 yang menunjukkan adanya hubungan dengan perkembangan sosial anak usia dini. ${ }^{18}$

Pola asuh orang tua dalam mendidik anak sangatlah berpengaruh, hal ini bisa diamati dengan adanya kebiasaan-kebiasaan yang dimiliki anak dalam kehidupan sehari-hari seperti cara berbicara, cara bergaul dan cara bermain dengan teman sebanyanya. Pola asuh orang tua juga sangat berpengaruh terhadap kecerdasan dan prestasi anak prasekolah, ${ }^{11}$ karena orang tua merupakan keluarga pertama sebagai pendidik dan sebagai contoh serta figur bagi anak. Realita yang didapatkan sikap otoriter orang tua bisa menjadikan anak menjadi pembangkang serta sikap permisif menjadikan anak semena-mena dalam bertindak namun ketika orang tua dalam mengasuh anak bersifat demokratis anak menjadi lebih terbuka dan hangat. Oleh karena itulah, pentingnya bagi orang tua untuk mendidik anak dengan pola asuh yang baik dengan selalu mengespresikan kasih sayang untuk anak agar anak bisa memiliki pribadi yang baik, berkarakter, berintelegensi dan berprestasi. Hal ini akan sangat berpengaruh terhadap perkembangan anak sejak dini yang meliputi perkembangan motorik kasar, motorik halus, bahasa, berkomunikasi dan bersosialisasi.

Menurut asumsi peneliti, terdapatnya hubungan bermakna pola asuh orang tua dengan perkembangan anak prasekolah, hal ini dikarenakan dapat dilihatnya dari persentase pola asuh yang tidak berisiko terdapat dari banyak anak yang memiliki perkembangan yang sesuai dan sebaliknya adanya kecenderungan persentase pola asuh orang tua yang berisiko akan diikuti oleh semakin banyaknya perkembangan anak yang tidak sesuai. Untuk itu, pola asuh sangat diperlukan untuk mendukung perkembangan anaknya, orang tua hendaknya selalu melakukan stimulasi sesuai umur sehingga perkembangan anak dapat berjalan dengan sesuai.

\section{SIMPULAN DAN SARAN}

Diperoleh sebanyak $36 \%$ perkembangan anak prasekolah yang tidak sesuai, $26 \%$ responden dengan tingkat pengetahuan orang tua kurang baik, $34 \%$ pola asuh orang tua yang berisiko. Hasil penelitian ini menunjukkan kurang dari separuh responden dengan perkembangan tidak sesuai, tingkat pengetahuan kurang baik, dan pola asuh orang tua berisiko Untuk hubungan tingkat pengetahuan responden dengan perkembangan anak didapatkan $p$ value $=0,000(p<0,05)$ dan untuk hubungan pola asuh orang tua dengan perkembangan anak didapatkan $p$ value $=0,000(p<0,05)$, sehingga adanya hubungan tingkat pengetahuan orang tua dan pola asuh dengan perkembangan anak prasekolah di TK Darul Falah Kelurahan Lubuk Buaya Padang tahun 2019. 
Diharapkan bagi petugas kesehatan terutama bidan pemegang program pemantau perkembangan untuk memberikan informasi dan edukasi kepada orang tua terutama ibu sebagai pendidik pertama anak di rumah tentang pentingnya melalukan pemantauan perkembangan anak dan memberi stimulasi perkembangan anak sesuai usianya, serta mengupayakan dan menyosialisasikan stimulasi perkembangan anak dengan penyuluhan dan promosi kesehatan mengenai perkembangan anak prasekolah untuk orang tua, sehingga dapat meningkatkan pengetahuan tentang perkembangan anak prasekolah dan pola asuh orang tua tidak berisiko agar anak dapat berkembang sesuai usianya.

\section{DAFTAR PUSTAKA}

1. Fida M. Pengantar Ilmu Kesehatan Anak. Yogyakarta: D-Medika; 2012.

2. UNICEF Indonesia. Laporan Tahunan. In 2012. Available from: https://www.unicef.org/indonesia/id

3. Widati A. Pengaruh Terapi Bermain: Origami Terhadap Perkembangan Motorik halus dan Kognitif Anak Usia Prasekolah (4-5 tahun) tahun 2012. 2012; Available from: https://eprints.ums.ac.id

4. Hidayat AA. Pengantar IImu Keperawatan Anak 1. Surabaya: Salemba Medika; 2011.

5. Soetjiningsih. Tumbuh Kembang Anak. Jakarta: EGC; 2013.

6. Departemen Kesehatan RI. Profil Kesehatan Indonesia tahun 2016. In Kementrian Kesehatan RI; 2016.

7. Soetjiningsih. Perkembangan Anak Sejak Pembuahan Sampai dengan Kanak-kanak Akhir. Depok: Prenadamedia Group; 2018.

8. Kementerian Kesehatan Republik Indonesia. Buku Ajar Kesehatan lbu dan Anak. Departemen Kesehatan Republik Indonesia. 2015.

9. Kemenkes RI. Laporan Nasional RISKESDAS 2018. Badan Penelitian dan Pengembangan Kesehatan. Badan Penelitian dan Pengembangan Kesehatan; 2018.

10. Lasiyati. Hubungan Pola Asuh Orang tua dengan Pertumbuhan dan Perkembangan Personal Social, Motorik dan Bahasa Anak Usia Prasekolah di PAUD Al-Hidayah Mojokerto. 2012; Available from: https://scholar.google.co.id

11. Kementerian Kesehatan RI. Kondisi Pencapaian Program Kesehatan Anak Indonesia tahun 2015. In: Profil Kesehatan Info Datin. Jakarta: Kementrian Kesehatan RI; 2015.

12. Syah M. Psikologi Belajar. Jakarta: PT. Raja Grafindo Persada; 2013.

13. Friedman. Buku Ajar Keperawatan Keluarga Riset, Teori \& Praktik. Jakarta: Buku Kedokteran EGC; 2010.

14. Dinas Kesehatan Kota Padang. Profil Kesehatan Kota Padang. In Padang: Dinas Kesehatan Kota Padang; 2017.

15. Nasir A. Buku Ajar Metodologi Penelitian Kesehatan. Yogyakarta: Nuha Medika; 2011. 
16. Kosoregan I. Hubungan Tingkat Pengetahuan Orang Tua Tentang Stimulasi Dini dengan Perkembangan Anak Usia 4-5 tahun di Desa Ranoketang Atas. ejournal keperawatan (e-Kp) [Internet]. 1(1). Available from: https://scholar.google.co.id/ejournal.unsrat.ac.id/index.php/jkp/article/view/2187

17. Handayani, Anik, Samiasih, Amin, Mariyam. Hubungan Tingkat Pengetahuan Orang Tua Tentang Stimulasi Verbal Dengan Perkembangan Bahasa Pada Anak Prasekolah Di Tk Pgri 116 Bangetayu Wetan. J Keperawatan. 2013;6(2):76-83.

18. Budiman. Kapita Selekta Kuesioner: Pengetahuan dan Sikap dalam Penelitian Kesehatan. Jakarta: Salemba Medika; 2013.

19. Zahro AA. Hubungan tingkat pengetahuan ibu tentang stimulasi verbal dengan perilaku membaca cerita pada anak di Dusun Petet Desa Tuntang Kecamatan Tuntang Kabupaten Semarang. Univ Sebel maret surakarta $J$ [Internet]. Available from: https://digilib.uns.ac.id/dokumen/detail/10713/

20. Apriastuti. Analisis Tingkat Pendidikan dan Pola Asuh Orang Tua dengan Perkembangan Anak Usia 48-60 Bulan di Desa Mudal Boyolali. Bidan Prada J Publ Kebidanan Akbid YLPP Purwokerto [Internet]. 2013; Available from: https://index.php/Prada/article/view/28

21. Hurlock. Psikologi Perkembangan Edisi 5. Jakarta: Erlangga; 2014.

22. Setia D. Hubungan tingkat pola asuh dengan perkembangan sosial anak usia dini di TK Negeri Pembina 2 Kota Jambi tahun 2017 [Internet]. 2017. Available from: https://repository.unja.ac.id/2525/ 